INTERnational JOURNAL OF MULtidisciplinaRy Research AND ANALysis

ISSN(print): 2643-9840, ISSN(online): 2643-9875

Volume 04 Issue 10 October 2021

DOI: 10.47191/ijmra/v4-i10-11, Impact Factor: 6.072

Page No.- 1418-1421

\title{
Metaphor is an Important Means of Perception of The Universe
}

\author{
Zafar BekpulatovichUmurkulov \\ Doctor of Philology (PhD) Termez State University Uzbekistan
}

ABSTRACT: One of the ways of figurative expression of thought with the help of linguistic means is metaphor. The article discusses the role of metaphor in the perception of the world; the basis for the formation of metaphors is the expression of new meanings and concepts.

KEYWORDS: metaphor, comparison-metaphor, comparison, images, artistic.

\section{INTRODUCTION}

The metaphor is considered from ancient times as a "decoration of speech", on its basis it is recognized that there is an figurative, attractive expression of thought. The ancient views on the origin of metaphor reflect the main essence of this figurative expression. Aristotle puts forward the idea that the analogy is also a metaphor, there is little difference between them, it is a means of analogy ${ }^{1}$ andall metaphors are analogies and analogy can be a metaphor, when the idea that the means of analogy does not participate ${ }^{2}$, but Cicero called it a metaphor ${ }^{3}$ and B. Tomashevsky interpreted the metaphor as an abbreviated form of analogy ${ }^{4}$.

\section{THE MAIN RESULTS AND FINDINGS}

Scientific sources on metaphor say that the basis of metaphor is a logical concept of analogy and comparison. M. Mukarramov wrote in his book "Analogy in Uzbek": "In metaphor and analogy, two objects or events are compared to each other on the basis of a particular sign. But in analogy, the thing and event being compared are expressed in lexical units, and the words are used in the correct sense. That is, an analogy consists of a simulated object, a simulated image, and a simulated character, consisting of a three-component or simulated object and a simulated image, with two components. The metaphor, on the other hand, consists only of the analogous image itself, and the object to be imitated can have a figurative meaning in itself" ${ }^{5}$, so Yuldashev describes the metaphor as an "abbreviated analogy"

These ideas show that there is a commonality in the origins of metaphor and analogy. What actually distinguishes them is the fact that the metaphor is formed on the basis of the derivative meaning, the words in the analogy have their own meaning, as well as the fact that the metaphor consists of one component and the analogy consists of two components. M. Mirtojiev shows that the metaphor is a manifestation of the formation of derivative meaning, the basis for the formation of derivative meaning is the existence of a comparison between the original meaning and the derivative meaning ${ }^{7}$.Emphasizing that derivative meaning is based on the comparison of referents ${ }^{8}$, the scientist points out that a simple metaphor is the appearance of derivative meaning based on the simple comparison, simulation of the reciprocal sign, properties of the derivative and derivative referents ${ }^{9}$. These ideas confirm that the basis of expression of both metaphor and analogy is analogy.Sh.Makhmaraimova, who conducted a special study on metaphor commenting on G.N.Sklyarevskaya's opinion that the metaphor is studied in 11 independent directions, in addition to this classification, notes that the metaphor should be

\footnotetext{
${ }^{1}$ Античные теории языка и стиля. М. - Л.: 1936. - С. 179.

${ }^{2}$ Ibid.,p. 180.

${ }^{3}$ Ibid., p. 216.

${ }^{4}$ Томошевский Б.В. Стилистика и стихосложения. - М.: 1952. - С. 222.

${ }^{5}$ Мукаррамов М. Ўзбек тилида ўхшатиш. - Тошкент: Фан, 1976. - Б. 11.

${ }^{6}$ Йўлдошев М. Чўлпон сўзининг сирлари. - Тошкент: Маънавият, 2002. - Б. 68.

${ }^{7}$ Миртожиев М. Ўзбек тили семасиологияси. Тошкент: Mumtozso'z, 2010. - Б. 81.

${ }^{8}$ Ibid., p.80.

${ }^{9}$ Ibid., p. 97
} 


\section{Metaphor is an Important Means of Perception of The Universe}

interpreted as a separate type of analogy ${ }^{10}$. These ideas confirm that the basis of expression of both metaphor and analogy is analogy.

Metaphor is a method of creating new meanings and concepts based on the creation of images using linguistic means, it is a method of expression based on thinking, human perception, feeling, and something perceived, comparison of common features in events. Metaphor is distinguished by a variety of methods of formation from other pictorial means. The fact that the sign on which the metaphorical meaning is based is not a general sign specific to the objects often ensures the expressive originality of the metaphor, and metaphors of this type become a criterion of artistic expression. It is well known that the use of a linguistic tool in a metaphorical sense creates emotionality, affectivity, and imagery in artistic speech, regardless of the character on which it is based.These speech possibilities occur in metaphorical expressions on the basis of the comparison of object, object-event signs with another, the expression of concepts that are not known in advance on the basis of certain similarities, arising as a result of imagination.The feature of originality and individuality in metaphors is stronger than in other means. M. Mukarramov believes that the essence of any metaphor is based on the expression of metaphors, and they arise on the basis of abstract thinking ${ }^{11}$.

The source of the using of metaphors and the purpose of their application also show that at the heart of this pictorial means lie not only expressions related to the activity of the sensory organs, but also conscious perceptions of existence'sot only, but alsometaphor is a means of artistic speech and it is an important means of expression that defines the essence of that speech.

In all the research on metaphor, it has been pointed out that there is a metaphor-based analogy as an important aspect of it.Thinking about the synesthetic metaphor, Sh. Makhmaraimova expresses its important feature as follows: "Synesthesia is a form of metaphor in which the derivative is compared to a reference made by another sense of meaning, forming a referent whose meaning is perceived with a certain intuition ${ }^{12}$. The comparison in the references may or may not be specific to the references. Accordingly, metaphors are divided into types such as simple and artistic metaphors in the sources ${ }^{13}$.M. Mirtojiev distinguishes three types of metaphors, showing that in a simple metaphor the external sign of referents is based on direct similarity, and the other types are based on the comparison of references ${ }^{14}$. The division of metaphors into such types as simple and artistic metaphors is distinguished by the fact that linguistic metaphors do not have an artistic color, they have a common feature, as they are used in artistic texts.

Simple metaphors in literary texts arise as a result of the transfer of meaning based on similarity between a particular sign between an object, an event, an animal, and a human being. For example, ...Шунда у бирдан умидсизланиб, шу нахангларнинг домига тушмай, тинчгина қишлоғига жўнаворгиси хам келади. (Ў.Усмонов. “Гирдоб”). The metaphorical meaningful word наханг(shark) in the text is used to describe man. Although there is no superficial resemblance between наханг(shark) and man, in a negative sense there is a resemblance between man's "greed, his attempt to take everything for himself," and this resemblance is a simple resemblance that is constantly known and felt by the human senses. Accordingly, these forms of metaphor are simple metaphors based on a certain similarity, conformity in references.It is often used in literary texts to express metaphorical words such as cunning, mastery of the fox, ignorance, rudeness of the bear, and looting of state property of the rat. For example, the expression of the warriors through бургутлар(the eagles) metaphor in sentence Maйли, Бобур куздаги ғалабасидан фахрланиб, қизига Фахринисо деб от қўйсин, керилиб, шеърини ёзиб ётаверсин. Унгача мен бургутларимнинг хаммасини овга ўргатаман (П.Қодиров. “Юлдузли тунлар") is also found on the basis of a simple suffix.There are similarities between a hunter-gatherer eagle and a warrior attacking an enemy army, such as the speed of movement, the achievement of a goal, these characters are the basis for metaphorical meaning. There are no simple similarities in the forms of metaphor that are formed on the cognitive knowledge of metaphor.In such metaphors, the character on which the metaphorical meaning is based is contrasted, compared to what is imagined, not to its simple resemblance to another character.In fact, in this type of metaphor, there is no resemblance between referents, no definite commonality either. However, in some cases, it will be possible to compare them based on certain characteristics. For example, Бухорои шарифни спекуляция қилиб, ислом миллатини захарловчи микроблар бизни шу холга келтирдилар. (Чўлпон. “Кеча ва кундуз”) Тhе word микроб (microbe) means that it causes various diseases. In this sense, those who have a negative color and have signs of

\footnotetext{
${ }^{10}$ Махмараимова Ш. Оламнинг миллий лисоний тасвирида теоморфик метафоранинг когнитив аспекти. Филология фанлари бўйича фалсафа доктори (PhD) илмий даражасини олиш учун ёзилган диссертация. - Қарши, 2018. - Б. 21.

${ }^{11}$ Мукаррамов, ор.cit., p.15.

${ }^{12}$ Махмараимова, ор.cit, p.111.

${ }^{13}$ Мукаррамов,op. cit. p.13.

${ }^{14}$ Ibid., p. 13 .
} 


\section{Metaphor is an Important Means of Perception of The Universe}

evil in the imagination are compared to a microbe. In this text, lack of knowledge, ignorant people, who could not distinguish between black and white, all the officials of that time were compared to microbe, based on the similarity between the microbe causing disease, the misleading of the people by ignorant, foolish people, and the consequent bad consequences. It is well known, however, that the similarity between these states is a resemblance that is perceived and compared by the imagination in the mind, not by the conformity of appearance, character, or feature.

In linguistics, metaphors are classified into several types according to their different characteristics. Among these classifications, Professor M. Mirtojiev's classification of types according to the formation of metaphors is of special importance ${ }^{15}$.In this classification, the formation of the metaphor is based on the type of similarity between the lexical meaning of the word and the derivative semantic references: simple similarity, similarity according to the function of the external sign, similarity perceived and compared by intuition. When approached from the perspective that metaphor is a visual medium that creates imagery, this classification highlights the essence of metaphor.The figurative, artistic form of the metaphor, in which the signs are exaggerated, is perceived through the imagination, the imagination, and is formed on the basis of comparison with another character in the mind, in the imagination.Accordingly, it is permissible to use the term metaphors in relation to this type of metaphor.Although there are similarities at the base of the metaphor, the similarity also arises as a result of mutual comparison. For example, Бу булутли хавони очмоқ фақат онанинг вазифаси эди. (Чўлпон. "Кеча ва кундуз") [It was only the mother's job to disperse the cloudy weather.]. The metaphorical expression of булутли хаво (cloudy weather) in this sentence is used to express sadness (face). The constant sadness, the resemblance of the face of a character whose eyelids do not open to a cloudy day, the compatibility of which is manifested in the comparison of these two things.

In comparison-metaphors, the basis of comparison is in perceptual observation. In simple metaphors, the metaphorical meaning is expressed based on the specificity of the objects seen and felt in both objects, while in comparison-metaphors such a sign is specific to one of the objects, and the sign in the second is perceived and compared to the first. For example, Унинг хаёти хам тиниқ бир булоқ бўлиб оқмаганмиди? Кейин бу булоқнинг устига жарлар қулаб, уни лойқалатди. Лекин хали бу булоқ қуриган эмас, унинг оби хаёти Хумоюннинг қалбини обод қилгани мана хозир билиниб турибди. (П.Қодиров. “Юлдузли тунлар") Characteristic in terms of the use of metaphorical expressions in this text булоқ, жар, лойқа, қуриган эмас, оби хаёти, обод қилмоқ words and phrases are used in a metaphorical sense.Derivative references in the text, хаёт (spring), жар (difficult, tragic days for Babur), лойқа (anxious, anxious life), қуриган эмас (ongoing life), обихаёт(inspired by Humayun from Babur's work), обод қилмоқ (learning from) the relationship between the meanings is the product of comparison through perception.

The characters that form the basis for comparison in metaphors are complex characters that are not understood by everyone. Accordingly, this form of metaphor has an individual character, and according to the nature of the character being compared, they can be divided into three types: a) metaphors to be compared on the basis of definite signs; b) metaphors to be compared on the basis of a common sign; c) metaphors to be compared on the basis of figurative perception. In metaphors that are compared on the basis of clear signs, the comparable signs of the referents are clear. For example, The metaphor ел тегирмони in the sentence Зайнаб хам кундоши юрагини ун қилувчи ел тегирмонини туххатишга мажбур булди (А.Қодирий. "Ўткан кунлар") was used to express the fan. The basis for the comparison of the fan and the hand mill is that both rotate and form wind. This sign is a definite sign that characterizes objects, and metaphors that are compared on the basis of clear signs differ from ordinary metaphors in that there is individuality in the comparison of the fan to the hand mill. This difference is primarily seen in the presence of imagery in the resulting metaphor. The булутли юз in the sentence Ва шу сўзларни айтаркан, унинг булутли юзларида жиндеккина очилиш аломатлари кўринди (Чўлпон. "Кеча ва кундуз") is compared on the basis of its relation to булутли осмонга. The signs between these comparisons are also clear signs that are characteristic of the objects being compared, such as the unopened, sad look on the face and the cloudy sky.

The metaphors, which are formed on the basis of a common character, also have the character of originality, individuality, and are a means of enhancing the imagery and impact of the literary text. In this case, the characters are compared on the basis of common features, without a clear sign between the meaning expressed by the metaphor and the original meaning of the word in the metaphorical sense. For example, Ой ботгач, осмон жимир-жимир юлдузларга тўлиб кетган, хаммаёқ сув қүйгандек жимжит, фақат Фармоновнинг юрагида бўрон. (О.Ёқубов. “Оққушлар, оппоқ қушлар...”). Farmonov's son was hit by a man in the car, the father was restless when he heard the news, his mind was disturbed by various things, and the metaphor of the storm was used to express the situation on the basis of the comparison of the situation to бурон (the storm).Although there are no clear similarities between storm and Farmonov's condition, there are general

${ }^{15}$ Миртожиев,op. cit., pp. 97-100. 


\section{Metaphor is an Important Means of Perception of The Universe}

similarities. It can be observed that there are also common features between the metaphor in the following sentences and the meanings they represent.Совуқ изғирин (cold storm) "bad news", довул (storm) "bad days ahead", қора булут (black cloud) "bad days", қуёш чиқади (sunrise) "good days" are metaphors used in the sentences Лекин хозир унинг қалбида қандайдир совуқ изғирин хуруж қилмоқда эди. (П.Қодиров. “Юлдузли тунлар”), Нахот, сокин дарёдай бир меъёрда оққан бу хаёт довулга учраса? (О.Ёқубов. “Улуғбек хазинаси”), Шахар осмонида айланган қора булутлар тарқаб, баайни қуёш чиқади. Қон, дахшад иси келиб турган шахарда тўй-томоша бошланиб кетади (Ш.Холмирзаев. “Қил кўприк") the original meaning and metaphorical meaning are formed according to the existence of a common character.

A characteristic form of metaphors is metaphors that are formed as a result of figurative perception. It reflects man's conscious activity in perceiving the world. Such metaphors arise not only on the basis of similarity, but as a product of human thought, and lead to the emergence of new meaning, new artistic images. Metaphor is the criterion of art. When approached from the point of view that its main source is artistic speech, the value of metaphors that emerge on the basis of figurative perception is manifested in artistic speech. This type of metaphor emerges as a result of a figurative image based on logical observation and allows for an effective, clear expression of thought. In the sources, such terms as artistic metaphor, poetic metaphor, synesthetic metaphor have been used to refer to this form of metaphor.Because both the reason for the emergence of such metaphors and the basis of the name migration will be aimed at the artistic expression of thought. For example, Oфат булути кутилмаган тезликда, кутилмаган ёвузлик дўлини ёғдириб бу махаллага хам етиб келди. Булутнинг совуқ шабадасини аввал Йигитали келтирди. (Т.Малик. “Шайтанат"). The meaning expressed through the metaphorical combinations офат булути (cloud of disaster), ёвузлик дўли(hail of evil), булутнинг совуқ шабадаси (cold breeze of the cloud) used in the text is an example of artistic observation based on comparisons between people who quarreled, their animosity, and the cold message of conflict.

The metaphorical combinations of офат булути (cloud of disaster) and булутнинг шабадаси (gentle wind of cloud) in the above sentences are compared to the devastation caused by "war" in the expression of the meaning of war, hail and heavy rains from behind the black cloud. The specific characters that exist based on the way these concepts are expressed through metaphorical meanings are not easily understood. - Хазрат ботаётган офтобга қаради. - Тағин қанча юраман? қуёшим ботгунча... Лекин энди орқага қайтиш йўқ! (Ш.Холмирзаев. “Қил кўприк")There is a logical basis for comparing ending life to the setting sun.Apparently, a comparison of the relationship between the metaphor and its referent leads to the metaphor.

\section{CONCLUSION}

In general, metaphors are an important means of revealing the specific features of a literary text, the expressive and methodological possibilities of metaphor in literary texts in comparison with other means of speech are wide and diverse in terms of formation.

\section{REFERENCES}

1) Античные теории языка и стиля. М. - Л.: 1936.

2) Махмараимова Ш. Оламнинг миллий лисоний тасвирида теоморфик метафоранинг когнитив аспекти. Филология фанлари бўйича фалсафа доктори (PhD) илмий даражасини олиш учун ёзилган диссертация. - Қарши, 2018.

3) Мукаррамов М. Ўзбек тилида ўхшатиш. - Тошкент: Фан, 1976.

4) Миртожиев М. Ўзбек тили семасиологияси. Тошкент: Mumtoz so'z, 2010.

5) Томошевский Б.В. Стилистика и стихосложения. - М.: 1952.

6) Йўлдошев М. Чўлпон сўзининг сирлари. - Тошкент: Маънавият, 2002.

7) Хидирова И. Тоғай Мурод асарида бўш қахрамонларнинг нутқидаги социопрагматик холатлар // Сўз санъати халқаро журнал.4 жилд, 3-сон. - Б. 202-205. 